\title{
PEMENUHAN HAK-HAK PENDIDIKAN KEAGAMAAN ISLAM ANAK BINAAN DI LEMBAGA PEMASYARAKATAN PAKJO PALEMBANG
}

\begin{abstract}
Ermis Suryana,
Baldi Anggara

Dosen Fakultas Ilmu

Tarbiyah dan

Keguruan UIN Raden

Fatah Palembang
\end{abstract}

\begin{abstract}
Abstrak
Latar belakang pemilihan judul ini didasarkan pada kajian empiris dan teoretis, bahwa pembinaan yang diberikan bagi Anak Binaan sudah selayaknya harus di perhatikan dengan baik. Anak merupakan generasi penerus bangsa oleh karena itu, anak harus diberikan kasih sayang agar anak dapat tumbuh dan berkembang dengan baik. Seorang anak yang tidak mendapat kasih sayang, ia akan cenderung menjadi anak yang nakal dan akibatnya dapat melakukan perbuatan yang menyimpang yang melanggar undang-undang. Anak yang demikian harus menjalani proses pidana yang berujung pada suatu pembinaan yang terjadi di Lembaga Pemasyarakatan Anak. Salah satu bentuk pembinaan yang ada di Lembaga Pemasyarakatan Anak adalah pembinaan yang bersumber pada individu anak. Pembinaan itu disebut dengan pembinaan anak secara perorangan (individual treatment).
\end{abstract}

Metode penelitian yang digunakan adalah deskriptif kualitatif. Penelitian deskriptif kualitatif bertujuan untuk mengangkat fakta, keadaan dan fenomena yang terjadi ketika penelitian berlangsung dan menyajikan data apa adanya.

Pelaksanaan dalam pemenuhan hak-hak pendidikan keagamaan Islam juga tidak terlepas dari kendala yang ada, baik itu struktur, substansi, dan kultur. Pada struktur, pembinaan anak perorangan memerlukan kuantitas dan kualitas dari tenaga pembina yang berhadapan langsung dengan anak didik. Pada substansi, peraturan perundang-undangan mengenai anak mengakibatkan timbulnya stigma yang membekas pada diri anak. Pada kultur, sangat dibutuhkan peran pihak di luar Lembaga Pemasyarakatan Anak (LPA), yaitu keluarga dan masyarakat.

Dari ketiga kelemahan tersebut hanya menekankan pada kesejahteraan anak mendorong munculnya pembinaan retroaktif. Pembinaan secara retroaktif dilakukan dengan melibatkan pihak-pihak yang ada di sekitarnya, yaitu pelaku, keluarga, masyarakat, dan tidak tertutup kemungkinan korban sehingga membina anak dilakukan secara lebih manusiawi karena juga tetap diperhatikan kepentingan lainnya, yaitu masyarakat dan korban.

Hal lain yang mendukung keberhasilan pembinaan anak didik pemasyarakatan adalah adanya partisipasi dari orang tua, keluarga, dan masyarakat. Dengan memperhatikan dan bersikap mau menerima anak tersebut, maka program pembinaan yang dilaksanakan di Lembaga Pemasyarakatan Anak (LPA) akan berjalan dengan baik dan berhasil.

Kata Kunci: Pendidikan Keagamaan, Anak Binaan, Lembaga Pemasyarakatan. 


\section{PENDAHULUAN}

Undang-Undang Dasar Negara Republik Indonesia Tahun 1945 Pasal 31 ayat (1) menyebutkan bahwa setiap warga negara berhak mendapat pendidikan, dan ayat (3) menegaskan bahwa Pemerintah mengusahakan dan menyelenggarakan satu sistem pendidikan nasional yang meningkatkan keimanan dan ketakwaan serta akhlak mulia dalam rangka mencerdaskan kehidupan bangsa yang diatur dengan undang-undang. Untuk itu, seluruh komponen bangsa wajib mencerdaskan kehidupan bangsa yang merupakan salah satu tujuan negara Indonesia. Sedangkan Misi pendidikan nasional adalah mengupayakan perluasan dan pemerataan kesempatan memperoleh pendidikan yang bermutu bagi seluruh rakyat Indonesia serta membantu dan memfasilitasi pengembangan potensi anak bangsa secara utuh sejak usia dini sampai akhir hayat dalam rangka mewujudkan masyarakat belajar; meningkatkan kesiapan masukan dan kualitas proses pendidikan untuk mengoptimalkan pembentukan kepribadian yang bermoral. Untuk mewujudkan misi tersebut perlu dilakukan langkah dan strategi diantaranya adalah pelaksanaan program wajib belajar.

Wajib belajar adalah program pendidikan minimal yang harus diikuti oleh warga Negara Indonesia atas tanggung jawab Pemerintah dan pemerintah daerah. Wajib belajar ini merupakan salah satu program yang gencar digalakkan oleh Departemen Pendidikan Nasional (Depdiknas). Dalam Undang-undang No. 20 tahun 2003, Pasal 6 ayat 1 bahwa: "Setiap warga negara yang berusia tujuh sampai lima belas tahun wajib mengikuti pendidikan Dasar". Program ini mewajibkan setiap warga Negara Indonesia untuk bersekolah selama 9 (sembilan) tahun pada jenjang pendidikan dasar, yaitu dari tingkat kelas 1 Sekolah Dasar (SD) atau Madrasah Ibtidaiyah (MI) hingga kelas 9 Sekolah Menengah Pertama (SMP) atau Madrasah Tsanawiyah (MTs), atau bentuk lain yang sederajat.

Wajib belajar ini sasaranya adalah setiap warga negara yang berusia 7-15 tahun. Artinya setiap warga negara yang berusia tujuh sampai dengan lima belas tahun wajib mengikuti pendidikan dasar dengan mengikuti program wajib belajar. Sementara pemerintah dan pemerintah daerah wajib menjamin terselenggaranya wajib belajar minimal pada jenjang pendidikan dasar tanpa memungut biaya. Sebab wajib belajar merupakan tanggung jawab negara yang diselenggarakan oleh lembaga pendidikan Pemerintah, pemerintah daerah, dan masyarakat. 
Untuk melaksanakan program Wajib belajar 9 tahun sebagai payung hukumnya, pemerintah telah mengeluarkan peraturan pemerintah no 47 tahun 2008 tentang pelaksanaan wajib belajar sembilan tahun. Dalam ketentuan umum di sebutkan bahwa program wajib belajar diselenggarakan untuk memberikan pelayanan pendidikan dasar seluas-luasnya kepada warga negara Indonesia tanpa membedakan latar belakang agama, suku, sosial, budaya, dan ekonomi. Setiap warga negara Indonesia usia wajib belajar berhak mendapatkan pelayanan pendidikan yang bermutu dan orang tua/walinya berkewajiban memberi kesempatan kepada anaknya untuk mendapatkan pendidikan dasar.

Lebih dari 4.000 anak Indonesia diajukan ke Pengadilan setiap tahunnya atas kejahatan ringan seperti pencurian. Perlindungan hukum bagi anak dapat diartikan sebagai upaya perlindungan hukum terhadap berbagai kebebasan dan hak asasi anak (fundamental rights and freedoms of children) serta berbagai kepentingan yang berhubungan dengan kesejahteraan anak. Jadi masalah perlindungan hukum bagi anak mencakup lingkup yang sangat luas (Barda Nawawi Arief, 1998: 153).

Sehubungan dengan hal tersebut di atas menurut Gatot Supramono “Kejahatan tersebut selain diakibatkan karena pengaruh lingkungan juga pribadi anak tersebut mengalami perkembangan fisik dan perkembangan jiwa. Emosinya belum stabil, mudah tersinggung dan peka terhadap kritikan, sehingga mempengaruhi dirinya untuk bertindak yang kadang-kadang tidak umum dan di luar aturan yang berlaku di masyarakat" (Gatot Supramono, 2007: 3-4).

Anak yang berkonflik dengan hukum dapat didefinisikan anak yang disangka, dituduh atau diakui sebagai telah melanggar undang-undang hukum pidana. Sedangkan menurut Pasal 1 butir 2 Undang-undang Nomor 3 Tahun 1997 tentang pengadilan anak bahwa anak yang berkonflik dengan hukum dikategorikan dengan anak nakal. Yang dimaksud dengan anak nakal adalah Anak yang melakukan tindakan pidana, atau Anak yang melakukan perbuatan yang dinyatakan dilarang bagi anak, baik menurut peraturan perundang-undangan maupun menurut peraturan hukum lain yang hidup dan berlaku dalam masyarakat yang bersangkutan. (Wagini Soetodjo, 2005: 11).

Perlindungan anak, yang diusahakan dengan memberikan bimbingan/pendidikan dalam rangka rehabilitasi dan resosialisasi menjadi landasan peradilan anak. Pasal 1 butir 1 UU No.4 Tahun 1979 menentukan: 
"Kesejahteraan anak adalah suatu tata kehidupan dan penghidupan anak yang dapat menjamin pertumbuhan dan perkembangannya dengan wajar baik secara rohani, jasmani, maupun social" (Maidin Gultom, 2006: 77).

Masalah anak-anak adalah kompleks, sehingga menarik untuk dibicarakan, apalagi pada saat ini kejahatan anak-anak menunjukkan persentase yang cukup bagi anak-anak sendiri maupun bagi masyarakat pada umumnya. Masalah kejahatan anak merupakan bahaya yang dapat mengancam masa depan masyarakat suatu bangsa, oleh karena itu mereka adalah "a generation who will on day become our notional leader".

Tujuan penanganan tersebut adalah untuk dapat memulihkan kondisi psikologis dan kondisi sosial serta fungsi sosial anak sehingga mereka dapat hidup, tumbuh dan berkembang secara wajar di masyarakat serta menjadi sumber daya manusia yang berguna label dan stigma masyarakat negatif terhadap anak yang menghambat tumbuh kembang mereka untuk berpartisipasi dalam hidup dan kehidupan masyarakat (Pedoman Operasional, 2004).

Untuk membantu kelancaran dalam proses memulihkan kondisi psikologis dan kondisi sosial serta fungsi sosial anak, maka diperlukan peranan petugas kemasyarakatan yang salah satunya petugas pemasyarakatan sebagai penegak hukum yang ditetapkan dalam pasal 33 Undang-undang No. 3 Tahun 1997. (Soedjono Dirdjosiworo, 1981: 27).

Pembinaan atau bimbingan merupakan sarana yang mendukung keberhasilan negara menjadikan narapidana menjadi masyarakat. Lembaga Pemasyarakatan berperan di dalam pembinaan narapidana, yang memperlakukan narapidana agar lebih baik. Yang perlu dibina adalah pribadi narapidana, membangkitkan rasa harga diri yang mengembangkan rasa tanggung jawab untuk menyesuaikan diri dengan kehidupan yang tentram dan sejahtera dalam masyarakat, sehingga potensial menjadi manusia yang berpribadi dan bermoral tinggi. (Maidin Gultom, 2006: 140).

Dalam undang-undang Nomor 12 Tahun 1995 pasal 2 tentang Pemasyarakatan bahwa : "Sistem pemasyarakatan diselenggarakan dalam rangka membentuk warga binaan pemasyarakatan agar menjadi manusia seutuhnya, menyadari kesalahan, memperbaiki diri, dan tidak mengulangi tindak pidana sehingga dapat diterima kembali oleh lingkungan masyarakat, dapat aktif berperan 
dalam pembangunan, dan dapat hidup secara wajar sebagai warga yang baik dan bertanggung jawab".

Dengan adanya pemasyarakatan itu maka perlu ditetapkan Peraturan Pemerintah Nomor 31 Tahun 1999 tentang Pembinaan dan Pembimbingan Warga binaan pemasyarakatan. Peraturan ini menjelaskan Pembinaan dan Pembimbingan bagi Warga Negara Binaan Pemasyarakatan selama dalam Lembaga Pemasyarakatan serta penjelasan mengenai hak dan kewajiban warga binaan pemasyarakatan.

Lembaga pemasyarakatan berfungsi sebagai tempat pembinaan/pendidikan, anak didik mempunyai tugas melaksanakan pemasyarakatan narapidana/anak didik. Untuk menyelenggarakan tugas tersebut, lembaga pemasyarakatan mempunyai fungsi sebagai berikut: (Romli Atmasasmita, 1975: 127).

a. Melakukan pembinaan narapidana/anak didik;

b. memberikan bimbingan, persiapan sarana dan mengelola hasil kerja;

c. melakukan bimbingan sosial kerohanian terhadap narapidana/anak didik;

d. melakukan pemeliharaan keamanam dan mematuhi tata tertib lembaga kemasyarakatan;

e. melakukan urusan tata usaha rumah tangga.

Jadi fungsi lembaga pemasyarakatan yakni tempat melakukan pembinaan narapidana/anak didik, memberikan bimbingan, persiapan sarana dan mengelola hasil kerja, melakukan bimbingan sosial kerohanian terhadap narapidana/anak didik, melakukan pemeliharaan keamanan dan mematuhi tata tertib lembaga kemasyarakatan, melakukan urusan tata usaha rumah tangga.

Tujuan Lembaga Pemasyarakatan menurut R. Achmad Soemadipraja dan Romli Atmasasmita, menyatakan bahwa tujuan lembaga pemasyarkatan adalah:

a. Berusaha agar narapidana, anak didik tidak melanggar hukum lagi di masyarakat kelak;

b. menjadikan narapidana, anak didik sebagai para peserta yang aktif dan kreatif dalam hal pembangunan;

c. membantu narapidana, anak didik kelak dapat berbahagia di dunia dan akhirat. (Ahmad Soemadipraja dan Romli Atmasasmita, 1979: 24).

Pada Lembaga Pemasyarakatan Kelas IIA Anak Pakjo Palembang terakhir pada bulan Maret 2012 jumlah anak didik terdapat 245 orang yang terdiri dari berbagai kasus. Di antaranya kasus pembunuhan, pencurian, pelecehan seksual 
dan narkoba. Hampir semua kasus dilatarbelakangi oleh faktor lingkungan, faktor keluarga dan faktor ekonomi. Tujuan pemidanaan menurut sistem pemasyarakatan sekarang ini telah diatur di dalam Undang-undang Nomor 12 Tahun 1995 tentang pemasyarakatan, di dalam Pasal 1 butir ke 1 menyatakan pemasyarakatan adalah kegiatan untuk melakukan pembinaan dalam hal pendidikan warga binaan pemasyarakatan berdasarkan sistem, kelembagaan dan cara pembinaan yang merupakan bagian akhir dari sistem pemidanaan dalam tata tertib peradilan pidana. Tujuan dari pendidikan tersebut diharapkan dapat memasyarakatkan terpidana anak sehingga menjadikannya orang yang baik dan berguna, menyelesaikan konflik yang ditimbulkan tindak pidana, memulihkan keseimbangan dan mendatangkan rasa damai dalam masyarakat serta membebaskan dari rasa bersalah.

Lembaga Pemasyarakatan Anak Klas IIA Pakjo Palembang merupakan salah satu unit Pelaksanaan Teknis dari 21 Unit Pelaksanaan Teknis di bidang Pemasyarakatan daerah Sumatera Selatan dan merupakan satu-satunya lapas khusus anak. Dengan 67 (enam puluh tujuh) orang pegawai yaitu laki-laki 59 orang dan perempuan 8 orang.

Jumlah narapidana pada bulan Maret 2012 adalah 245 orang yang terdiri dari berbagai kasus. Di antaranya kasus pembunuhan, pencurian, pelecehan seksual dan narkoba. Hampir semua kasus dilatarbelakangi oleh faktor lingkungan, faktor keluarga dan faktor ekonomi. Adanya ketidakseimbangan antara petugas dan narapidana dalam sarana prasarana sehingga mempengaruhi proses pendidikan narapidana tersebut. Hal ini akan mengakibatkan tidak mempunyai rasa jera sehingga setelah keluar dari Lembaga Pemasyarakatan akan melakukan lagi perbuatan pidana karena tidak mempunyai ketrampilan yang dapat diandalkan.

Pada dasarnya Lembaga Pemasyarakatan Anak Klas IIA Palembang tidak ubahnya seperti Lembaga Pemasyrakatan pada umumnya. Dasar yuridis operasionalnya sama-sama menganut Undang-undang No.12 Tahun 1995 tentang pemasyarakatan. Salah satu konsep yang sama dilihat dari tujuan akhir di mana pembinaan pendidikan dan bimbingan terhadap warga binaan sama dengan binaan pendidikan terhadap anak didik yang dilaksanakan di Lembaga Pemasyrakatan Anak Pakjo Palembang yakni mengarah pada penyatuan (integrasi) kehidupan didalam masyarakat. Berangkat dari upaya Lembaga Pemasyarakatan dalam 
tujuan pokoknya, maka penulis berkeinginan untuk meneliti bagaimana proses Lembaga Pemasyarakatan sebagai tempat pembinaan/pendidikan terhadap narapidana anak secara keseluruhan yang diterapkan terhadap mereka. Dari kerangka pemikiran di atas, maka cukup menarik untuk di kaji tentang: PEMENUHAN HAK-HAK PENDIDIKAN KEAGAMAAN ISLAM ANAK BINAAN (STUDI KASUS DI LEMBAGA PEMASYARAKATAN ANAK KLAS IIA PAKJO PALEMBANG). Berdasarkan uraian di atas, maka pokok permasalahan yang akan di kaji dalam penelitian ini adalah:

a. Bagaimana pemenuhan hak-hak pendidikan keagamaan Islam anak binaan di Lembaga Pemasyarakatan Anak Kelas IIA Pakjo Palembang?

b. Faktor-faktor apa saja yang mempengaruhi dalam pemenuhan hak-hak pendidikan keagamaan Islam anak binaan di Lembaga Pemasyarakatan Anak Kelas IIA Pakjo Palembang?

\section{METODOLOGI PENELITIAN}

1. Sumber Informasi

Di dalam penelitian ini informasi yang didapat yakni dari anak binaan, Kalapas, dan petugas pendidikan Lapas secara langsung. Informasi dalam penelitian ini digunakan untuk mengumpulkan data-data tentang pemenuhan hak-hak pendidikan keagamaan Islam anak binaan di Lembaga Pemasyarakatan Klas IIA Pakjo Palembang.

2. Jenis dan Sumber Data

a. Jenis data

Adapun jenis data yang digunakan dalam penelitian ini yakni data kualitatif. Data kualitatif yaitu data yang berupa keterangan tentang pemenuhan hak-hak pendidikan keagamaan Islam anak binaan di Lembaga Pemasyarakatan Klas IIA Pakjo Palembang.

b. Sumber data

Pertama : Data Primer, yaitu data yang diperoleh secara langsung dari hasil penelitian di lapangan, baik melalui wawancara, dokumentasi dan pengamatan dengan pihak kepala Lembaga Pemasyarakatan Anak beserta jajarannya dan pihak narapidana atau anak binaan di Lembaga Pemasyarakatan Anak Klas IIA Palembang. 
Kedua: Data sekunder, yaitu data yang diperoleh dari penelitian kepustakaan dengan menelusuri literatut-literatur, peraturan perundang-undangan, pendapat para ahli hukum yang relevan dengan pokok pembahasan.

3. Metode Pengumpulan Data

Dalam penelitian ini, pengumpulan data menggunakan metode sebagai berikut:

a. Metode Wawancara

Wawancara adalah proses memperoleh keterangan untuk tujuan penelitian dengan cara tanya jawab sambil bertatap muka antara pewawancara dengan informan atau orang yang diwawancarai dengan menggunakan pedoman wawancara.

Metode ini digunakan untuk memperoleh data secara mendalam mengenai seluruh komponen yang ada di Lemabaga Pemasyarakatan yang berkenaan dengan pembahasan yang mengenai pendidikan keagamaan Islam anak binaan di Lapas Pakjo Palembang.

b. Metode Dokumentasi

Dokumentasi adalah suatu cara pengumpulan data yang dapat berupa arsip, tulisan-tulisan yang dapat dijadikan bukti atau petunjuk terhadap sesuatu. (Koentjaraningrat, 2006, hal. 25). Metode ini dipakai dengan meneliti dokumen dan catatan Lapas dengan maksud agar data yang diperoleh lebih objektif, seperti, sejarah Lapas, sarana dan prasarana, jadwal kegiatan pembinaan Lapas, jumlah petugas Lapas, tenaga Pembina dan anak binaan.

c. Metode Observasi

Observasi adalah suatu metode atau cara untuk mendapatkan data dengan jalan mengamati secara langsung objek yang diteliti oleh peneliti. (Sutrisno Hadi, 1996, hal. 136). Metode ini digunakan untuk melakukan pengamatan secara langsung terhadap objek penelitian, yaitu untuk mengetahui bagaimana pemenuhan hak-hak pendidikan keagamaan Islam anak binaan di Lembaga Pemasyarakatan Pakjo Palembang.

\section{Teknik Analisa Data}

Di sini peneliti menggunakan deskriptif kualitatif, yaitu dengan seluruh data yang tersedia, memberi gambaran dan keadaan atau status fenomena yang diteliti dengan menggambarkan berupa kata-kata, dan diabstraksikan 
kemudian disusun dalam satuan-satuan, setelah itu dikategorisasikan dan diambil kesimpulan dari data tersebut. Data-data itu berasal dari naskah wawancara lapangan, dokumentasi, observasi dan lain sebagainya. Analisa yang dimaksud yakni mendeskripsikan dan menguraikan tentang pembinaan dalam rangka proses pelaksanaan pendidikan keagamaan bagi narapidana atau anak binaan di Lembaga Pemasyarakatan yang meliputi pelaksanaan dalam pendidikan keagaman Islam yang diperoleh pada saat melakukan penelitian, baik itu dari hasil wawancara, dokumentasi, observasi, ataupun lainnya.

\section{PEMBAHASAN}

\section{Pengertian Pendidikan Keagamaan Islam}

Menurut Zakiah Daradjat, bahwa pendidikan keagamaan adalah merupakan pembinaan mental (kepribadian) seseorang yang sudah dimulai sejak kecil melalui proses interaksi dan pengalaman-pengalaman, yang didalamnya terdapat nilainilai agama, moral dan sosial kemasyarakatan. (Zakiah Daradjat, 1980: 40).

Sedangkan dalam PP. No. 55 Tahun 2007. Pendidikan keagamaan adalah pendidikan yang mempersiapkan peserta didik untuk dapat menjalankan peranan yang menuntut penguasaan pengetahuan tentang ajaran agama dan/atau menjadi ahli ilmu agama dan mengamalkan ajaran agamanya.

Berdasarkan definisi di atas dapat diartikan bahwa pendidikan keagamaan Islam merupakan pembinaan kepribadian yang dimulai sejak masih kecil yang di dalamnya tergabung nilai-nilai dan pengalaman-pengalaman baik yang disadari atau tidak, yang pada akhirnya akan menentukan corak kepribadian seseorang di kemudian hari.

Pendidikan keagamaan dapat dilaksanakan dengan metode pembinaan dan pendidikan secara menyeluruh, seperti metode yang dilaksanakan di pondokpondok pesantren dalam membentuk kepribadiaan bagi anak didik yang berdampak sangat positif demi kelangsungan pembinaan generasi muda, sebagai generasi penerus bangsa. Sebagaimana yang menjadi tujuan dari system pemasyarakatan dalam rangka membentuk Warga Binaan Pemasyarakatan agar menjadi manusia seutuhnya, menyadari kesalahan, memperbaiki diri, dan tidak mengulangi tindak pidana, sehingga dapat diterima kembali oleh lingkungan masyarakat, dapat aktif berperan dalam pembangunan dan dapat hidup secara wajar sebagai warga yang baik dan bertanggung jawab. 


\section{Pengertian Anak Berdasarkan UU Peradilan Anak}

Anak merupakan individu yang berada dalam satu rentang perubahan perkembangan yang dimulai dari bayi hingga remaja. Masa anak merupakan masa pertumbuhan dan perkembangan yang dimulai dari bayi (0-1 tahun) usia bermain (1-2,5 tahun), pra sekolah (2,5-5), usia sekolah (5-11 tahun) hingga remaja (11-18 tahun). (Akmal Hawi, 2005: 84).

Menurut Undang-Undang No. 4 Tahun 1979 tentang Kesejahteraan Anak, Pasal 1 butir 2, yang dimaksud anak adalah seorang yang belum mencapai umur 21 (dua puluh satu) tahun dan belum pernah kawin.

Kitab Undang-Undang Hukum Perdata (KUHP) memberikan batasan mengenai pengertian anak atau orang yang belum dewasa adalah mereka yang belum berumur 21 (dua puluh satu) tahun. Seperti yang dinyatakan dalam Pasal 330 yang berbunyi : "Belum dewasa adalah mereka yang belum mencapai umur genap dua puluh satu tahun, dan tidak lebih dahulu kawin".

Pengertian tentang anak secara khusus dalam pasal 1 angka (1) UndangUndang Nomor 23 Tahun 2002 Tentang Perlindungan Anak, dan pasal 1 angka (5) Undang-Undang Nomor 21 Tahun 2007 Tentang Pemberantasan Tindak Pidana Perdagangan Orang, yaitu : "Anak adalah seseorang yang belum berusia 18 (delapan belas) tahun, termasuk anak yang ada dalam kandungan”.

Sedangkan menurut pasal 1 angka (5) Undang-Undang Nomor 39 Tahun 1999 tentang pengertian anak adalah : "Anak adalah setiap manusia yang berusia di bawah 18 (delapan belas) tahun dan belum menikah, termasuk anak yang masih dalam kandungan apabila hal tersebut adalah demi kepentingannya".

Sedangkan menurut pasal 1 angka (1) Undang-Undang Nomor 3 Tahun 1997 Tentang Pengadilan Anak, pengertian anak yaitu: “Anak adalah orang yang dalam perkara Anak Nakal telah mencapai umur 8 (delapan) Tahun tetapi belum mencapai umur 18 (delapan belas) Tahun dan belum pernah kawin”.

Dalam hal ini pengertian anak dibatasi dengan syarat sebagai berikut: pertama, anak dibatasi dengan umur antara 8 (delapan) sampai dengan 18 (delapan belas) tahun. Sedangkan syarat kedua si anak belum pernah kawin. Maksudnya tidak sedang terikat dalam perkawinan ataupun pernah kawin dan kemudian cerai. Apabila si anak sedang terikat dalam perkawinan atau perkawinanya putus karena perceraian, maka sianak dianggap sudah dewasa walaupun umurnya belum genap 18 (delapan belas) tahun. 


\section{Pengertian Anak Nakal}

Pengertian anak nakal telah dirumuskan dalam Pasal 1 butir 2 UU No. 3 tahun 1997 sebagai berikut: Anak Nakal adalah anak yang melakukan tindak pidana, dan anak yang melakukan perbuatan yang dinyatakan terlarang bagi anak baik menurut peraturan perundang-undangan maupun menurut peraturan hukum lain yang hidup dan berlaku dalam masyarakat yang bersangkutan.

Menurut Maulana Hassan Wadong dalam bukunya "Pengantar Advokasi Dan Hukum Perlindungan Anak" mengemukakan, bahwa ketentuan kejahatan anak atau delinquency anak diartikan sebagai bentuk kejahatan yang dilakukan anak dalam titel-titel khusus dari bagian KUHP dan atau peraturan perundangundangan. (Maulana Hasssan Wadong, 2000: 21).

Sedangkan menurut Sudarto, anak nakal adalah: Yang melakukan tindak pidana; yang tidak dapat diatur dan tidak taat kepada orang tua/wali/pengasuh; yang sering meninggalkan rumah, tanpa ijin/sepengetahuan orang tua/wali/pengasuh; yang bergaul dengan penjahat-penjahat atau orang-orang yang tidak bermoral, sedang anak itu mengetahui hal itu; yang kerap kali mengunjungi tempat-tempat yang terlarang bagi anak-anak; yang seringkali menggunakan katakata kotor; yang melakukan perbuatan yang mempunyai akibat yang tidak baik bagi perkembangan pribadi, sosial, rohani dan jasmani anak itu.

\section{Kenakalan Anak}

Kenakalan anak diambil dari istilah asing Juvenile Delinquency. Juvenile artinya young, anak-anak, anak muda, ciri karakteristik pada masa muda sifat-sifat khas pada periode remaja, sedangkan delinquency artinya doing wrong, terabaikan/mengabaikan, yang kemudian diperluas artinya menjadi jahat, kriminal, pelanggar aturan, pembuat ribut, pengacau, penteror, tidak dapat diperbaiki lagi, durjana, dursila, dan lain-lain. (Wagiati Soetodjo, 2006: 8-9).

Menurut Kartini Kartono, juvenile delinquency ialah kejahatan/kenakalan anak-anak muda merupakan gejala sakit (patologis) secara sosial pada anak-anak dan remaja yang disebabkan oleh suatu bentuk pengabaian sosial, sehingga mereka itu mengembangkan bentuk tingkah laku yang menyimpang. (Kartini Kartono, 2008: 6). Sedangkan Menurut Fuad Hassan, yang dikatakan juvenile delinquency adalah perbuatan anti sosial yang dilakukan oleh remaja, yang apabila 
dilakukan oleh orang dewasa maka dikualifikasikan sebagai kejahatan. (Wagiati Soetodjo, 2006: 10).

Dari pendapat-pendapat para ahli maupun yang terdapat dalam peraturan perundang-undangan, dapat dikatakan bahwa ada kesamaan, khususnya mengenai pengertian anak nakal. Jadi anak nakal pada dasarnya merupakan anak yang melakukan perbuatan yang dilarang oleh perundang-undangan ataupun melanggar norma-norma yang ada dan pelaku dari perbuatan tersebut adalah orang yang belum dewasa dan belum pernah kawin.

\section{Undang-Undang No. 3 Tahun 1997 tentang Pengadilan Anak}

Latar belakang lahirnya Undang-Undang Pengadilan Anak, (http:www. napi1708. blogspot. com/20 Mei 2007. diakses tanggal 10 Juni 2012).

a. Bahwa anak adalah bagian dari generasi muda salah satu sumber daya manusia yang merupakan potensi dan penerus cita-cita perjuangan bangsa, yang memiliki peranan strategis dan mempunyai ciri dan sifat khusus, memerlukan pembinaan dan perlindungan dalam rangka pertumbuhan dan perkembangan fisik, mental, dan sosial secara utuh, serasi selaras dan seimbang.

b. bahwa untuk melaksanakan pembinaan dan memberikan perlindungan terhadap anak, diperlukan dukungan, baik yang menyangkut kelembagaan maupun perangkat hukum yang lebih mantap dan memadai, oleh karena itu ketentuan mengenai penyelenggaraan pengadilan bagi anak perlu dilakukan secara khusus.

Dengan adanya Undang-Undang Pengadilan Anak, diharapkan dapat menangani masalah perkara anak, mulai dari tingkat pertama sampai tingkat terakhir dan kepentingan si anak tetap dapat terlindungi hak-haknya.

\section{Sistem Pemasyarakatan Anak}

Menurut Undang-Undang No.12 Tahun 1995 tentang Pemasyarakatan, Pasal 1 angka 1 menjelaskan tentang definisi pemasyarakatan yaitu kegiatan untuk melakukan pembinaan warga binaan pemasyarakatan berdasarkan sistem, kelembagaan, dan cara pembinaan yang merupakan bagian akhir dari sistem pemidanaan dalam tata peradilan pidana. Jadi pemasyarakatan mempunyai makna pembinaan terhadap narapidana supaya nantinya dapat kembali ke masyarakat. 
pembinaan itu dapat berjalan dengan baik apabila didukung oleh suatu sistem yang dinamakan sistem pemasyarakatan.

Menurut Pasal 1angka 2 Undang-Undang No.12 Tahun 1995 tentang Pemasyarakatan menyebutkan bahwa sistem pemasyarakatan adalah suatu tatanan mengenai arah dan batas serta cara pembinaan warga binaan pemasyarakatan berdasarkan Pancasila yang dilaksanakan secara terpadu antara pembina, yang dibina, dan masyarakat untuk meningkatkan kualitas warga binaan pemasyarakatan agar menyadari kesalahan, memperbaiki diri, dan tidak mengulangi tindak pidana sehingga dapat diterima kembali oleh lingkungan masyarakat, dapat aktif berperan dalam pembangunan, dan dapat hidup secara wajar sebagai warga yang baik dan bertanggung jawab. Pembinaan terhadap warga binaan pemasyarakatan dilakukan di Lembaga Pemasyarakatan. Pembinaan yang dilakukan di Lembaga Pemasyarakatan ditujukan terhadap narapidana dan anak didik pemasyarakatan.

\section{Fungsi Lembaga Pemasyarakatan}

Sebagaimana terdapat dalam pasal 3 Keputusan Menteri Kehakiman RI Nomor. M.01-PR.07.03 Tahun 1985 tentang Organisasi dan Tata Kerja Lembaga Pemasyarakatan adalah: Melaksanakan Pembinaan dan Pendidikan narapidana dan anak pidana; memberikan bimbingan, mempersiapkan sarana dan mengelola hasil; melaksanakan bimbingan sosial / kerohanian narapidana dan anak pidana; melakukan pemeliharaan keamanan dan tata tertib; melakukan tata usaha dan rumah tangga pemasyarakatan.

Dari rumusan tersebut di atas dapat digaris bawahi bahwa sistem pemasyarakatan menghendaki partisipasi segenap komponen dalam pembinaan warga binaan pemasyarakatan baik pembina, narapidana maupun masyarakat. Menurut Keputusan Menteri Kehakiman RI Nomor M.01-PR.07.03 Tahun 1985 Tentang Organisasi dan Tata Kerja Lembaga Pemasyarakatan narapidana dan anak didik." Sedangkan menurut ketentuan Pasal 1 Ayat (3) Undang-Undang Nomor 12 Tahun 1995 Tentang Pemasyarakatan berbunyi: "Lembaga pemasyarakatan (LAPAS) adalah tempat untuk melaksanakan pembinaan/pendidikan narapidana dan anak didik pemasyarakan”.

Mengenai pelaksanaan pembinaan anak berdasarkan model pembinaan anak perorangan (individual treatment model) yang merupakan praktek penerapan 
pembinaan anak di Lembaga Pemasyarakatan Anak (LPA) yang berlaku saat ini (ius operatum) telah penulis uraikan sebelumnya. Segala kekurangan yang ada pada pelaksanaan pembinaan anak berdasarkan model pembinaan anak perorangan menuntut untuk dicari model pembinaan lain yang seharusnya dengan segala pertimbangan bagi kepentingan anak di masa datang (ius constituendum). Sebagaimana penulis telah sebutkan diatas, model pembinaan anak perorangan atau individual treatment model merupakan suatu model pembinaan anak yang telah dilaksanakan di Lembaga Pemasyarakatan Anak. Pelaksanaan pembinaan secara individual ini telah dikenal tetapi dalam pelaksanaannya belum dapat diterapkan dengan baik. Model pembinaan anak perorangan atau individual treatment model berguna untuk mengobati anak yang melakukan perbuatan melanggar hukum. Anak akan mendapatkan pelayanan terapi khususnya untuk mengobati sakitnya melalui suatu pembinaan dengan tujuan agar setelah selesai menjalani pembinaan, ia dapat kembali ke lingkungannya semula.

Muladi mengemukakan secara rinci ciri-ciri peradilan restoratif, berikut ini: Kejahatan dirumuskan sebagai pelanggaran seseorang terhadap orang lain dan dipandang sebagai konflik; fokus perhatian pada pemecahan masalah pertanggungjawaban dan kewajiban untuk masa datang; sifat normatif dibangun atas dasar dialog dan negosiasi; restitusi sebagai sarana perbaikan para pihak, rekonsiliasi dan restorasi merupakan tujuan utama; keadilan dirumuskan sebagai hubungan antar hak, dinilai atas dasar hasil; fokus perhatian terarah pada perbaikan luka sosial akibat kejahatan; masyarakat merupakan fasilitator di dalam proses restoratif; peran korban dan pelaku diakui, baik dalam penentuan masalah maupun penyelesaian hak-hak dan kebutuhan korban. Pelaku didorong untuk bertanggung jawab; pertanggungjawaban pelaku dirumuskan sebagai dampak pemahaman atas perbuatannya dan diarahkan untuk ikut memutuskan yang terbaik; tindak pidana difahami dalam konteks menyeluruh, moral, sosial dan ekonomis, stigma dapat dihapus melalui tindakan restoratif. (Muladi, 1995: 127129). 


\section{HASIL PENELITIAN}

\section{Pelaksanaan Pembinaan Anak di Lembaga Pemasyarakatan Anak Pembinaan secara umum}

Menurut Haposan Silalahi selaku kepala pembina, program-program pembinaan secara umum bagi anak didik pemasyarakatan yang telah dilaksanakan di Lembaga Pemasyarakatan Anak adalah sebagai berikut: Kegiatan Belajar berupa Kelompok Belajar (Kejar), Pendidikan Agama, Pendidikan Keterampilan, Pendidikan Kepramukaan dan Kewarganegaraan, Perpustakaan, Pelayanan Kesehatan dan Makanan (Wawancara, 17 Mei 2012).

Mengenai hak dan kewajiban anak didik pemasyarakatan, menurut Muhammad Junaidi selaku pembina adalah sebagai berikut : Hak mendapatkan tempat untuk tidur yang memenuhi syarat-syarat kesehatan; mendapatkan makan dan minum serta perlengkapannya; mendapatkan pakaian dengan warna dan potongan yang telah ditentukan; mendapatkan perlakuan secara manusiawi; mendapatkan keamanan dan ketentraman; mendapatkan pemeriksaan kesehatan dan pengobatan oleh para medis atau dokter; mendapatkan pendidikan, bimbingan umum, dam bimbingan kerohanian; beribadah menurut agama dan kepercayaan; kunjungan keluarga, handai taulan dan penasihat hukum selama tidak mengganggu ketertiban dan atas izin pejabat yang berwenang; menerima dan mengirim surat, uang atau barang berdasarkan ketentuan yang berlaku; membelanjakan uang titipan, simpanan miliknya dalam batas-batas kewajaran, untuk kepentingan dirinya sendiri berdasarkan ketentuan yang berlaku; menyampaikan permasalahan, baik yang bersifat gangguan secara fisik atau mental secara pribadi (Wawancara, 17 Mei 2012).

Sedangkan kewajiban anak binaan menurut Muhammad Junaidi selaku pembina di lembaga pemasyarakatan yakni: Mentaati dan mematuhi peraturan yang berlaku di Lembaga Pemasyarakatan Anak; menjaga dan memelihara ketentraman dan ketertiban; mengikuti petunjuk dan melaksanakan perintah sesuai dengan ketentuan berlaku; melaporkan dan memberitahukan keadaan akan hal-hal yang dapat berakibat terganggunya keamanan, ketertiban, dan ketentraman para petugas; menyerahkan uang serta barang lain yang dilarang untuk dibawa kepada petugas; menjaga dan memelihara tanaman dan kebersihan lingkungan; menjaga dan memelihara alat-alat perlengkapan yang telah diberikan untuk dirinya agar tetap utuh, bersih, dan rapi; mengikuti senam pagi, apel pagi 
sesuai dengan jadwal yang telah ditentukan; mengikuti program kegiatan pendidikan, bimbingan yang bersifat umum dan khusus yang diberikan kepada dirinya; melaksanakan pekerjaan yang diberikan, diperintahkan oleh petugas atau pejabat yang berwenang; melaksanakan ibadah menurut agama dan kepercayaan masing-masing dalam waktu dan tempat yang telah ditentukan; menjalin tata karma dan kesopanan terhadap sesama anak didik pemasyarakatan berdasarkan kekeluargaan; menyerahkan kembali alat-alat perlengkapan yang pernah dikuasainya pada saat pindah lepas dan meninggalkan Lembaga Pemasyarakatan Anak.

\section{Pembinaan secara individual atau perorangan}

Lembaga Pemasyarakatan Anak (LPA) telah lama melakukan pembinaan secara perorangan. Pembinaan secara individual yang ditujukan bagi anak didik pemasyarakatan yang dilakukan di Lembaga Pemasyarkatan Anak (LPA) adalah sebagai berikut: Pembinaan Keagamaan, seperti sholat berjamaah merupakan kegiatan rutin yang harus dilakukan oleh anak didik pemasyarakatan. Bimbingan Psikologi dilakukan oleh pembina Lembaga Pemasyarakatan Anak (LPA).

Menurut bapak Haposan Silalahi selaku pembina mengatakan bahwa dahulu kegiatan ini kurang mengena mungkin dikarenakan tingkah laku dari para anak didik/binaan pada masa itu yang kurang mau menerima masuknya lingkungan dari luar. Tetapi pada masa sekarang ini, dapat berlangsung dengan baik. Kegiatan yang dilakukan misalnya setiap bulan sekali ada anak yang selesai menjalani hukumannya. Sebelum anak tersebut pulang kerumah maka, anak tersebut diberikan pembinaan dulu secara khusus, dibekali agar ia dapat mempersiapkan diri sebelum keluar ke Lembaga Pemasyarakatan Anak (LPA) dan kembali ke masyarakat. Ada lagi suatu keadaan yang sering dijumpai yaitu rasa gelisah pada setiap anak di lingkungan Lembaga Pemasyarakatan Anak (LPA). Keadaan ini sering ditemui karena mereka sering merasa kangen pada keluarga. Terlebih lagi kebanyakan, keluarga mereka bertempat tinggal jauh dan keadaan mereka yang cenderung tidak mampu. Rasa kangen ini biasanya diatasi dengan mendatangi orang tua dari anak didik/binaan tersebut kelembaga Pemasyarakatan Anak (LPA), yang biayanya biasanya ditanggung dari Lembaga Swadaya Masyarakat (LSM) yang bekerjasama dengan Lembaga Pemasyarakatan Anak (Wawancara, 18 Mei 2012).

Dari hasil pengamatan penulis pembinaan secara individual yang dilakukan dengan pembina, sangat dilakukan dengan suasana kekeluargaan. Hal tersebut dapat tercermin dari hubungan yang terjalin antara pembina dengan anak didik selayaknya orang tua dengan anaknya sendiri. Pembina memberikan motivasi kepada anak didik dan menempatkan diri sebagai orang tua dari anak didik karena 
keadaan anak didik yang jauh dari orang tua dan tidak adanya kemampuan untuk bertemu dengan orang tua. Jadi, dengan terjalinnya hubungan itu maka timbul suatu kewajiban yaitu anak didik patuh terhadap pembina. (Pengamatan, 18 Mei 2012).

Menurut Iwan Supriadi selaku anak binaan mengatakan bahwa walaupun dia tidak dibina, tetapi mereka tetap senang, karena menurut mereka keadaan mereka yang diterima di lingkungan Lembaga Pemasyarakatan Anak (LPA). (Wawancara, 18 Mei 2012).

Pembinaan secara individual yang lebih disukai oleh anak didik adalah pembinaan dalam bentuk konseling."Menurutnya konseling sangat bermanfaat. Mereka menjadi lebih tenang dan mereka menjadi lebih terbuka serta bersemangat untuk merubah perilaku mereka menjadi lebih baik". (Wawancara, 18 Mei 2012).

Menurut bapak Pujo Harinto selaku Kalapas, mengatakan bahwa masih ada juga yang tidak ada interaksi dengan keluarga. Hal tersebut mungkin karena keluarga bertempat tinggal jauh dan tidak memiliki cukup uang untuk sekedar mengunjungi anaknya di Lembaga Pemasyarakatan Anak Pakjo Palembang. (Wawancara, 18 Mei 2012).

Berdasarkan pengamatan yang penulis lakukan selama mengadakan penelitian di Lembaga Pemasyarakatan Anak, mereka menempatkan kegiatan keagamaan sebagai program yang sangat berorientasi pada individu anak binaan. Pendapat tersebut didasarkan pada bukti bahwa Lembaga Pemasyarakatan Anak (LPA) telah memprogram kegiatan pembinaan keagamaan dalam waktu yang sesering mungkin. Penempatan kegiatan keagamaan dengan tujuan untuk meningkatkan keimanan dan ketakwaan kepada Tuhan Yang Maha Esa adalah hal utama yang harus dipupuk oleh anak didik/binaan sehingga mereka dapat menjalani kehidupannya di Lembaga Pemasyarakatan Anak (LPA) dengan baik maupun sebagai bekal untuk kehidupan di luar Lembaga Pemasyarakatan Anak. ( Pengamatan, 18 Mei 2012).

Berdasarkan wawancara penulis dengan dengan Suharli selaku anak binaan di Lembaga Pemasyarakatan Anak (LPA), dia mengatakatan bahwa:

"Sanksi yang diberikan ada sanksi ringan dan sanksi berat. Sanksi ringan diberikan apabila mereka terlambat bangun dua atau tiga kali, kurang rapi membersikan tempat tidur. Sedangkan sanksi berat diberikan kepada anak didik apabila mereka tidak melaksanakan sholat berjamaah dengan sungguhsungguh setelah mendapat teguran dari pembina dua atau tiga kali. Adapun 
bentuk dari sanksi ringan adalah membersihkan halaman Lembaga Pemasyarakatan Anak (LPA), dijemur, lari keliling lapangan, atau dilarang menonton televisi, sedangkan sanksi berat dapat berupa dimasukkan ke dalam sel pengasingan selama beberapa hari, tidak boleh berhubungan dengan anak didik yang lain dan tidak boleh menerima kunjungan dari siapapun termasuk keluarganya. Jadi begitu pentingnya kegiatan pembinaan keagamaan sehingga apabila terjadi pelanggaran oleh anak didik, misalnya tidak mengikuti sholat berjamaah maka akan dikenakan sanksi yang berat (Wawancara, Peneliti dengan Suharli selaku anak Lapas 18 Mei 2012).

\title{
Kegiatan Pendidikan Keagamaan di Lembaga Pemasyarakatan Anak
}

Pelaksanaan program Pendidikan Keagamaan Islam adalah merupakan program peningkatan pelaksanaan kinerja Lembaga Pemasyarakatan Anak Klas IIA Palembang yang berdasarkan fungsi dari Lembaga Pemasyarakatan, sebagaimana dijelaskan dalam Undang-undang No. 12 Tahun 1995 tentang Pemasyarakatan, pada bab I Ketentuan Umum Pasal 1 ayat 3, berbunyi: "Lembaga Pemasyarakatan yang selanjutnya disebut LAPAS adalah tempat untuk melaksanakan pembinaan Narapidana dan Anak Didik Pemasyarakatan”.

Selanjutnya tugas dan fungsi seksi Bimbingan Narapidana dan Anak Didik (Binadik) yang akan memberikan bimbingan narapidana/anak didik berdasarkan peraturan dan prosedur yang berlaku dalam rangka persiapan napi/anak didik kembali ke masyarakat, tidak melanggar hukum lagi dan berprilaku baik. Dalam hal ini tugas Sub Seksi Bimbingan dan Perawatan (Bimaswat), sebagaimana yang dikatakan oleh Kepala Sub Seksi Bimaswat:

\begin{abstract}
"Menyelenggarakan pembinaan mental/ rohani dan fisik serta meningkatkan pengetahuan assimilasi serta perawatan Napi/anak didik sesuai dangan peraturan yang berlaku dalam rangka kelancaran pelaksanaan tugas pemasyarakatan, maka dengan melalui program peningkatan pembinaan keagamaan, khususnya agama Islam, diharapkan narapidana maupun tahanan tampa kecuali mendapat pendidikan agama Islam sebagai bekal hidup di dunia dan akhirat. Meskipun kurang keseimbangan antara penghuni Lapas yang semakin meningkat dengan petugas Pemasyarakatan yang semakin berkurang, kegiatan pembinaan agama dan pendidikan Islam insyaallah tetap berjalan konsisten melalui koordinasi antar bagian dan partisifasi masyarakat dan lembaga-lembaga dakwah dan lembaga pendidikan”. (Wawancara dengan bapak Jam'an, 17 Mei 2012).
\end{abstract}

Hasil observasi dan hasil wawancara yang penulis lakukan terhadap anak didik pemasyarakatan sebagai berikut:

"Kegiatan Pembinaan yang kami ikuti seperti Penyuluhan Agama Islam dan Pengajian metode Iqro', sering mengalami hambatan, baik dari Ustaz yang mengajar maupun dari kami (anak didik) yang belajar ataupun pegawai yang 
mengeluarkan kami dan mengawal setiap ada jadwal Pengajian. Sehingga jadwal kegiatan sering tidak tepat waktu dan waktu yang tersedia untuk belajar sangat kurang". (Wawancara dengan Redi anak binaan, 20 Mei 2012).

Sebagaimana hasil wawancara yang disampaikan anak didik yang mengikuti kegiatan sebagai berikut:

"Semua kegiatan di Lapas wajib diikuti, jika kami tidak ikuti berarti kami tidak patuh, yang tentunya berakibat kepada kondite kami menjadi jelek dimata pegawai, akibatnya kami tidak akan dapat menerima pengurangan hukuman dan assimilasi. Dan kami juga sangat senang mengikuti kegiatankegiatan, disamping bermanfaat bagi masa depan kami, juga dapat mengisi waktu-waktu kami selama menjalani hukuman. untuk kembali kepada keluarga kami”. (wawancara Peneliti dengan Umar selaku anak lapas, 20 Mei 2012).

Untuk sholat Jum'at dilaksanakan di selasar (teras dalam kantor Lapas Anak), sebagaimana yang dikatakan oleh Kalapas Anak:

"Pelaksanaan sholat jum'at tidak dapat dilaksanakan di Masjid At-Taubah, mengingat daya tampungnya terbatas, disamping letak bangunan Masjid tidak strategis dari sisi pengamanan. Mengingat jumlah penghuni semakin bertambah maka digunakan di selasar (teras dalam kantor), sehingga memungkin semua penghuni baik Narapidana dan tahanan dapat mengikuti semua pelaksanan sholat jum'at, kecuali Andik yang non muslim ( ada 3 orang yang beragama Kristen) pelaksanaan kebaktian diruang konseling pada setiap hari sabtu jam 10.00 wib. (Wawancara peneliti dengan bapak Pujo H selaku Kalapas 20 Mei 2012).

Pemisahan ruang pendidikan anak binaan yang masih berstatus tahanan dengan anak binaan yang berstatus narapidana merupakan kebijakan yang harus dilaksanakan, karena anak didik mempunyai hak untuk menuntut ilmu, khususnya ilmu agama dan melaksanakan ibadah sesuai dengan kepercayaan dan keyakinannya. Dan masalah penempatan tahanan dan narapidana adalah wewenang Kepala Kesatuan Pengaman LP (KPLP), sebagaimana yang dikatakan oleh bapak Badaruddin, sebagai berikut:

"Penempatan ruang pembinaan agama bagi tahanan harus terpisah dari andik narapidana, mengingat dari segi pengamanan dan status anak didik yang masih titipan dari pihak Kepolisian, Kejaksaan dan Pengadilan. Anak didik yang masih berstatus tahanan harus diberikan pelayanan yang sebaik-baiknya, terutama dalam pelaksanaan ibadah, sedangkan Narapidana wajib diberikan pembinaan agama dan pendidikan umum serta pendidikan keterampilan". (Wawancara, 20 Mei 2012).

Jadi tugas staf pengamanan menjadikan keadaan dan situasi yang kondusif untuk kelancaran pelaksanaan tugas pembinaan, pendidikan dan kegiatan pembinaan keterampilan bagi anak didik. 
Berdasarkan wawancara dengan Bayumi selaku Kasubag TU yang menyatakan bahwa:

"Koordinasi yang dilakukan dalam kegiatan pembinaan keagamaan anak didik untuk selanjutnya dibuat laporan dengan membandingkan antara sasaran/ target yang ditetapkan dengan besarnya realisasi yang telah dicapai”. Alat yang digunakan dalam koordinasi antar bagian ini digunakan surat memo yang isinya dapat berupa kata-kata, seperti dilanjutkan, diteruskan dan ditinjau ulang. Surat memo tersebut dikirimkan untuk menanggapi suatu pelaksanaan tugas/pekerjaan. (Wawancara, 20 Mei 2012).

Berdasarkan hasil wawancara, dapat di simpulkan bahwa pelaksanaan tugas dan fungsi pada masing-masing seksi Lembaga Pamsyarakatan Anak Klas IIA Palembang telah dijalankan dan dikoordinasikan dengan baik. Dalam hal ini koordinasi antar bagian sangat diperlukan untuk memperlancar pelaksanaan tugas sehingga dapat terkoordinir dengan baik dan kemungkinan tumpang tindih pekerjaan dapat dihindari.

\section{Faktor yang mempengaruhi dalam pemenuhan pendidikan keagamaan}

\section{Islam anak binaan di Lembaga Pemasyarakatan}

Menurut Junaidi selaku pembina dapat penulis kemukakan berdasarkan 3 (tiga) komponen, yaitu:

1. Struktur Pembinaan anak secara perorangan atau individual memerlukan jumlah personil yang sangat banyak. Bahkan untuk mencapai hasil ideal, diperlukan 1 (satu) pembina untuk membina secara khusus 1 (satu) anak.

Menurut Muhammad Junaidi Kondisi inilah yang tidak mungkin untuk diterapkan karena jumlah pembina yang ada tidak mencukupi untuk membina masing-masing anak didik di Lembaga Pemasyarakatan Anak yang jumlahnya ratusan anak. Selain jumlah pembina, pembinaan secara perorangan ini juga memerlukan banyak adanya peran serta dari psikolog, khususnya psikolog anak dan tokoh agama untuk memberikan bekal keagamaan pada anak didik. (Wawancara peneliti dengan petugas pembina Lapas 20 Mei 2012).

Menurut penulis aspek lain yang penting adalah kualitas dari pembina. Pembina yang dibutuhkan adalah pembina yang benar-benar berkualitas dan sangat memahami masalah mengenai anak. Oleh karena itu harus diperhatikan betul kualitas dari pembina. Pembina yang berkualitas berarti harus sering mengikuti pendidikan khususnya untuk menangani masalah seputar anak nakal, oleh karena itu harus mempunyai dana yang lebih agar pembina dapat mendalami 
pendidikan yang mendaalm seputar masalah anak. Jadi kendala lainnya adalah dana. Penggunaan model pembinaan anak secara perorangan jelas membutuhkan dana yang tidak sedikit. Pembinaan secara individual membutuhkan banyak fasilitas berupa sarana dan prasarana yang memang secara khusus disediakan untuk anak didik. Fasilitas tersebut misalnya sel yang dihuni secara individual, dalam arti terpisah satu anak didik dengan anak didik yang lain, ruangan yang secara khusus benar-benar untuk mendukung jalannya pembinaan secara perorangan.

2. Substansi lebih mengarah kepada peraturan yang telah ada khususnya mengenai anak itu telah dijalankan dengan baik atau tidak. Selain itu, apakah peraturan perundang-undangan tersebut telah memenuhi hal-hal yang berkaitan dengan perlindungan anak, khususnya perlindungan anak nakal. Berdasarkan pengamatan penulis, anak didik di Lembaga Pemasyarakatan Anak (LPA) banyak yang dijatuhi pidana penjara. Kondisi inilah yang akan membuat jiwa dan beban anak didik tersebut semakin berat. Oleh karena itu, seharusnya peraturan perundang-undangan yang ada dapat digunakan bagi kepentingan anak saja karena peraturan perundang-undangan yang berlaku sekarang ini cenderung mengakibatkan stigma pada diri anak pelaku. (Pengamatan, 20 Mei 2012).

3. Kultur. Peran serta pihak lain sangat dibutuhkan dalam upaya rehabilitasi dan resosialisasi anak didik. Pihak pertama yang harus memberi dukungan adalah keluarga. Anak didik yang ada di Lembaga Pemasyarakatan Anak ini kebanyakan jauh dari keluarga. Walaupun banyak di antara mereka yang sering dikunjungi oleh keluarga, akan tetapi tidak sedikit pula yang jarang dikunjungi oleh keluarga. Selain keluarga, pihak lain yang penting adalah masyarakat. Lembaga Pemasyarakatan Anak (LPA) sering menerima adanya kunjungan sosial. Kunjungan sosial ini biasanya melibatkan lembaga masyarakat.

Kemudian menurut Fahriyudin dikatakan bahwa kendala-kendala yang lain adalah sebagai berikut: (Wawancara, 25 Maret 2012).

a. Hambatan yang bersifat personal yaitu, kurangnya kemauan atau niat dan kemampuan atau bakat yang dimiliki oleh anak didik/binaan di lembaga pemasyarakatan;

b. tenaga pengajar atau pendidikan yang kurang berkualitas; 
c. Hambatan yang bersifat fasilitatif yaitu : peralatan yang digunakan untuk makan, minum dan memasak sudah tidak layak untuk dipakai, buku-buku perpustakaan yang jumlahnya masih terbatas, fasilitas untuk kegiatan yang jumlahnya terbatas, fasilitas kesehatan yang masih sangat terbatas.

\section{KESIMPULAN}

Berdasarkan uraian dalam pembahasan dan analisa data, maka dapat ditarik kesimpulan sebagai berikut:

1. Upaya Lembaga Pemasyarakatan Terhadap Pemenuhan Hak-hak Pendidikan terhadap Anak Pidana di Lembaga Pemasyrakatan Anak Klas IIA Pakjo Palembang, yaitu: Bentuk dari pembinaan anak secara kelompok dan individual adalah pembinaan secara keagamaan dan konseling. Menyediakan sarana Fasilitatif yaitu berupa tenaga pengajar baik itu dari petugas Lembaga Pemasyarakatan Anak itu sendiri maupun tenaga ahli dari pihak luar yang diminta bantuan jasa sebagai pengajar dan pembimbing dan menyediakan sarana Substantif yaitu berbagai macam program kegiatan pendidikan. Program pendidikan formal seperti program pendidikan Paket A, Paket B dan Paket C. Sedangkan untuk pendidikan non formal seperti kegiatan, keterampilan menjahit, pendidikan montir, pendidikan kerohanian, serta pendidikan komputer.

2. Faktor-faktor yang mempengaruhi dalam Pemenuhan Hak-hak Pendidikan terhadap Anak didik/binaan di Lembaga pemasyarakatan Anak Klas IIA Pakjo Palembang, adalah dari struktur, substansi, dan kultur. Pada struktur, pembinaan anak perorangan memerlukan kuantitas dan kualitas dari tenaga pembina yang berhadapan langsung dengan anak didik. Pada substansi, peraturan perundang-undangan mengenai anak mengakibatkan timbulnya stigma yang membekas pada diri anak. Pada kultur, sangat dibutuhkan peran pihak di luar Lembaga Pemasyarakatan Anak (LPA), yaitu keluarga dan masyarakat. Hal lain yang mendukung keberhasilan pembinaan anak didik pemasyarakatan adalah adanya partisispasi dari orang tua, keluarga, dan masyarakat. Dengan memperhatikan dan bersikap mau menerima anak tersebut, maka program pembinaan yang dilaksanakan di Lembaga Pemasyarakatan Anak (LPA) akan berjalan dengan baik dan berhasil. Pembinaan yang benar-benar ditujukan untuk anak secara perorangan 
membutuhkan dana yang tidak sedikit. Dana tersebut diperlukan untuk menyediakan fasilitas berupa sarana dan prasarana, seperti ruangan khusus untuk pendukung pelaksanaan pembinaan secara perorangan, sel tempat tinggal yang dihuni oleh anak didik satu per satu, dan sebagainya. 


\section{DAFTAR PUSTAKA}

Bahar, Safroedin, 2000. Konteks Kenegaraan Hak azasi Manusia, Pustaka Sinar Harapan, Jakarata.

Dwidja Prayitno, 2006. Sistem Pelaksanaan Pidana Penjara di Indonesia, cetakan Pertama Refika Aditama, Bandung.

Gisita Arif, 1989. Masalah Perlindungan Anak, Akademi Pressindo, Jakarta.

Gultom Maidin, 2006. Perlindungan Hukum Terhadap Anak, Dalam Sistem Pradilan Pidana Anak di Indonesia, Rafika Aditama, Bandung.

Hakim Abdul Garuda Indonesia, 1996. Prospek Perlindungan Anak, Makalah Seminar Perlindungan Hak-hak Anak, Jakarta.

Hamzah dan Siti Rahayu, 1986. Suatu Tinjauan Ringkas Sistem Pemindahan Indonesia, Suatu Akademika Presindo, Jakarta.

http:www.napi1708.blogspot.com/20 Mei 2007. Di akses tanggal 8 maret 2012.

Nawawi Arief Barda, 1998. Beberapa Aspek Kebijaksanaan Penegakan dan Pengembangan Hukum Pidana, PT. Citra Aditya Bakti, Bandung.

Pedoman Oprasional, 2004. Pelayanan dan Rehabilitasi Sosial Bagi Anak Nakal di Panti Sosoial, Departemen Sosial RI Direktorat Jendral Pelayanan dan Rehabilitasi Sosial, Direktorat Bina Pelayanan SosialAnak, Jakarta.

Poernomo Bambang, 1986. Pelaksanaan Pidana Penjara dengan Sistem Pemasyarakatan, Liberty Yogyakarta.

Peraturan Pemerintah Nomor 31 Tahun 1999 tentang Pembinaan dan Pembimbingan Warga Binaan Pemasyarakatan.

Peraturan Pemerintah Nomor 32 Tahun 1999 tentang Syarat dan Tata Cara Pelaksanaan Hak Warga Binaan Pemasyarakatan.

Reksodiputro Marjono, 1984. Kriminologi Dalam Sistem Peradilan Pidana, Lembaga Kriminologi, Universitas Indonesia, Jakarta.

Sujanto, Adi, 2004. Sistem Pemasyarakatan Indonesia Membangun Manusia Mandiri, DirjenPemasyrakatan Departemen Hukum dan Ham RI, Jakarta.

Supromono Gatot, 2007. Hukum Acara Pengadilan Anak, Djambatan, Jakarta.

Suparni Niniek, 1993. Ekstensi Pidana Denda Dalam Sistem Pidana dan Pemidanaan, Sinar Grafika, Jakarta.

Saraswati Rika, 2009. Hukum perlindungan anak di Indonesia, PT. Citra Aditya Bakti, Bandung. 
Soemadipraja, R Ahmad dan Atmasasmita, Romli, 1979. Sistem Pemasyrakatan di Indonesia, Bina Cipta, Bandung.

Sudarto, 1984. Masalah Penghukuman dan Gagasan Pemasyrakatan Dalam Kapasitas Hukum Pidana, Bandung: Alumni.

Suhardjo, 1963. Pohon Beringin Pengayoman Hukum Pancasila Maripol/Usdek, Istana Negara, Jakarta.

Soekanto, Soeryono, 1983. Faktor-faktotr yang Mempengaruhi Penegakan Hukum, CV. Rajawali, Jakarta.

Soetedjo, Wagini, 2005. Hukum pidana anak, Rafika aditama, Bandung.

Surat Keputusan Menteri Kehakiman Republik Indonesia Nomor : M.02.PK.04.10- Tahun 1990 tentang Pola Pembinaan Narapidana / Tahanan.

Surat Keputusan Menteri Kehakiman Republik Indonesia Nomor : M.01.PR.07.03 Tahun 1985 tentang Orientasi dan Tata Kerja Lembaga Pemasyrakatan.

Undang-Undang Republik Indonesia Nomor 3 Tahun 1997 tentang Pengadilan Anak.

Undang-Undang Republik Indonesia Nomor 12 Tahun 1995 tentang Pemasyrakatan.

Waluyo Bambang, 2000. Pidana dan Pemidanaan, Sinar Grafika, Jakarta.

Yudowidagdo, 1987. Kapita Selekta Hukum Acara Pidana di Indonesia, Bina Aksara, Jakarta.

Yumono, Soesilo, 1982. Penyelesaian Perkara Pidana Berdasarkan KUHP, Alumni, Bandung. 